\title{
MASCULINIZATION OF TILAPIA (OREOCHROMIS NILOTICUS) BY IMMERSION METHOD USING METHANOL EXTRACT OF PASAK BUMI ROOTS (EURYCOMA LONGIFOLIA JACK)
}

\author{
Yusuf Noor Syarifuddin* \\ Department of Aquaculture, Faculty of Agriculture, University of Palangka Raya, \\ Palangka Raya, Central Kalimantan \& Doctoral Program, Faculty of Fisheries and Marine \\ Science, University of Brawijaya, Malang, East Java, Indonesia
}

Andayani Sri, Risjani Yenny, Faqih A. Rahem

Faculty of Fisheries and Marine Science, University of Brawijaya, Malang, East Java, Indonesia

*E-mail: $\underline{n \text { syarifuddin@yahoo.com }}$

\begin{abstract}
The use of synthetic steroids of 17-Methytestosterone (MT) to produce a monosexual population of male Tilapia (Oreochromis niloticus) has been restricted because it can leave harmful residues in fish and the environment. One alternative that can be done is by using natural bioactive derived from plants with androgenic properties, such as Pasak Bumi (Eurycoma longifolia Jack). The aim of this research was to assay the use of methanol extract from Pasak bumi roots with immersion techniques for masculinization of tilapia. The research procedure was carried out with three treatment doses of methanol extract from the Pasak Bumi roots (namely 30,60, and $90 \mathrm{mg} / \mathrm{L}$ ), treatment dose amounted to $0 \mathrm{mg} / \mathrm{L}$ acted as a negative control and treatment of MT amounted to $50 \mathrm{mg} / \mathrm{L}$ acted as a positive control, with three replications on each treatment. Immersion was applied to larvae that was hatched out of egg yolk (seven day-old) for 24 hours and was maintained with a capacity of 50 larvae per aquarium during 60 days. The results showed that the treatment of the methanol extract of Pasak Bumi roots gave male sex ratios ranging from $72.66 \%-76.33 \%$ higher than the negative control which showed the results of male sex ratios amounted to $49.19 \%$ and lower than the positive control of MT which the results amounted to $83.99 \%$. The range of survival rate was from $80.67 \%-85.33 \%$, while the range of survival rate in the negative control was $83.33 \%$ and in positive control of MT was $82.67 \%$. Thus, the methanol extract of Pasak Bumi roots can be used for masculinization of tilapia by immersion method with the best performance at a dose of $60 \mathrm{mg} / \mathrm{L}-90 \mathrm{mg} / \mathrm{L}$.
\end{abstract}

\section{KEY WORDS}

Monosex culture, pasak bumi, sex reversal, testosterone, tilapia fish.

Tilapia (Oreochromis niloticus) is one of the main consumption fish in Indonesia that has beneficial biological properties because it can consume various types of natural food, can grow well in all kinds of waters and has a high tolerance for low water quality. But the tilapia culture is disrupted by gonad which becomes mature too quickly, which can cause unwanted reproduction (wild breeding) which results in slow growth. One method to overcome the wild breeding is monosex culture (in this case, male fish) because the type of male tilapia has a growth rate of almost two times faster than that of female tilapia.

One method used to get male monosex fish is by using androgen hormones. One of the hormones that has commonly been used for maleization is $17 \alpha$-methyltestosterone. However, the use of MT has been limited because it can leave harmful residues in fish and the environment (Pandian \& Kirankumar, 2003). The use of the hormone of 17methyltestosterone in Indonesia has been banned (KKP 2014). One alternative that can be done is by using natural products derived from plants that are androgenic properties, such as Pasak bumi. 
Pasak bumi (Eurycoma longifolia Jack) is used as an active drug for men or it is commonly referred with the term aphrodisiac. Pasak bumi can increase the levels of testosterone, LH (Luteinizing Hormone), and FSH (Follicle Stimulating Hormone). Pasak bumi contains phytosterol, which has androgenic properties. The most common phytosterol found in plants is $\beta$-sitosterol and stigmasterol. $\beta$-sitosterol has an estrogenic effect that can increase vitellogenesis in female and male Rainbow Trout fish. Male fish liver cells are able to produce vitellogenin (Tremblay and Van der Kraak, 1998). Parks et al. (2001)reported that phytosterols isolated from paper pulp waste are able to masculinize Mosquitofish females (Gambusia affinis holbrooki). Masculinization using Purwaceng's (Pimpinella alpina) extract which is thought to contain stigmasterol is able to increase the population of male Tilapia (Putra, 2011), Betta fish (Betta splendens) (Bulkini, 2012 and Cahyani 2014) and Rainbow Fish (Iriatherina werneri) (Nurkhasanah, 2015).

The sex reversal application is performed to reverse the development of gonad sex in fish, from female to male. This process is carried out when the fish gonad has not been differentiated between male and female at the time of hatching. The gonad tissue of Teleostei fish when differentiated is very unstable. It is sensitive to environmental factors such as exogenous steroid hormones or xenobiotics (Govoroun et al., 2001). Piferrer (2001), the sensitivity of steroid hormones to the development of sex differentiation is very dependent on the phase of gonad development that occurs. In this case, the peak sensitivity occurs after the cell division phase of the gonad tissue or before differentiated gonad tissue. This phenomenon, according to Carman et al. (1998), occurs because the function of the sex chromosome in determining gender is not active yet.

The process of female sex differentiation in fish occurred when the P450 aromatase enzyme is produced during times of sex differentiation. P450 aromatase enzymes work to catalyze changes in androgen hormones to estrogen, so the P450 aromatase enzyme determines the balance between androgen and estrogen hormones. The process of inhibiting P450 aromatase activity at the receptor level during the period of sex differentiation causes changes in the female phenotype into the male phenotype (Pandian, 2013). Inhibition of CYP19 activity can be done by the administration of steroid hormones or with manipulating environment temperature (Bowman et al. 2012).

\section{MATERIALS AND METHODS OF RESEARCH}

The research was conducted for 4 months in the Fish Domestication and Breeding Laboratory, CV. Griya Aquatica - Fish Farming, Palangka Raya, Central Kalimantan.

This research consisted of three treatments and two control treatments. Each treatment was repeated three times. Each treatment applies different amount of dose of methanol extract of the Pasak Bumi roots by the immersion method. Treatment that was applied to tilapia larvae, namely:

Treatment without methanol extract of Pasak Bumi roots, as a negative control TH (K-);

Treatment with $30 \mathrm{mg} / \mathrm{L}$ of methanol extract of Pasak Bumi roots (EPB1);

Treatment with $60 \mathrm{mg} / \mathrm{L}$ of methanol extract of Pasak Bumi roots (EPB2);

Treatment with $90 \mathrm{mg} / \mathrm{L}$ of methanol extract of Pasak Bumi roots (EPB3);

Treatment with $50 \mathrm{mg} / \mathrm{L}$ of $17 \alpha-M e t h y l t e s t o s t e r o n e$, as a positive control of MT $(\mathrm{K}+)$.

The Pasak bumi (Eurycoma longifolia Jack) roots were obtained from Rakumpit Subdistrict, Palangka Raya, Central Kalimantan. The sample was dried and ground into flour. Then some of the Pasak Bumi root flour was wrapped in filter paper. Then it was extracted using the Soxhlet method with methanol solvent. Soxhlet ran at $70^{\circ} \mathrm{C}$ for 4 hours, so the solvent was evaporated by the condenser and dropped to the sample column. The extraction results were evaporated by using a rotary evaporator at $40^{\circ} \mathrm{C}$ to get the Pasak bumi extracts. Extracts that have been in the form of pasta were weighed according to the dose of treatment. $1,095 \mathrm{~g}$ of Pasak Bumi roots flour produced as much as $54.98 \mathrm{~g}$ of methanol extract with $4.93 \%$ percentage of extract mass. Then the Pasak Bumi methanol extract was analyzed by GC-MS (Table 1). The methanol extract of Pasak Bumi and 17a- 
methyltestosterone also observed nanostructures with scanning electron microscope (SEM) (Figure 1).

Table 1 - Results of GC-MS analysis of Methanol Extract of Pasak Bumi

\begin{tabular}{|c|c|c|c|}
\hline No. & Compounds Name & Suitability Factors (\%) & Total (\%) \\
\hline 1. & 3- (2-pentenyl) -1,2,4-cyclopentanetrion & 53 & 5.80 \\
\hline 2. & Palmitic acid methyl ester & 98 & 1.63 \\
\hline 3. & Palmitic acid & 99 & 10.39 \\
\hline 4. & 4-ethoxy-2,5dimethoxybeenzaldehyde & 60 & 2.23 \\
\hline 5. & Isophraxidine / 6,8-dimethoxy-7-hydroxy kumarin & 96 & 1.55 \\
\hline 6. & Methyl ester oleic acid & 99 & 1.44 \\
\hline 7. & Linoleic acid & 96 & 1.33 \\
\hline 8. & Oleic acid & 99 & 4.78 \\
\hline 9. & Octadecanoic acid & 97 & 1.16 \\
\hline 10. & 4-(5-propyl-2-pyridinyl) -benzonitrile & 58 & 7.95 \\
\hline 11. & Canthine-6-on(3,4-diazafluoranthen-2(3H)-on & 94 & 4.21 \\
\hline 12. & m-cresol / m-toluol / 3-methylphenol & 64 & 8.80 \\
\hline 13. & Diisooktylphthalate & 91 & 1.91 \\
\hline 14. & 4-phenyl-8-oxo-4,5,6,7-tetrahydroxyclopenta (b) -1,2,3-triazolo (4,5-e) pyridine & 90 & 6.98 \\
\hline 15. & 2-methyl-4,4-diphenyl-2-imidazolin-5-on & 91 & 3.95 \\
\hline 16. & Methyl ester, 1,2-dimethyl-ferocarboxylic acid & 49 & 4.73 \\
\hline 17. & Methyl ester 4,5-dihydroxy-4- (3-methyl-2-butenyl benzoic acid & 46 & 2.48 \\
\hline 18. & Unknown & 25 & 0.93 \\
\hline 19. & 3 - [(trimethylsilyl) oxy] -, acetate (17.beta) -estra-1,3,5, (10) -trienn-17-ol & 87 & 1.12 \\
\hline 20. & 5-heptadekatri-9(Z),11 (Z), $14(Z)$-enilresorsinol & 80 & 1.12 \\
\hline 21. & Piperin & 99 & 1.12 \\
\hline 22. & Salisildehid / beta resorsinaldehyde & 49 & 1.21 \\
\hline 23. & Metilenetanshinkuinon & 41 & 1.23 \\
\hline 24. & Unknown & 10 & 1.10 \\
\hline 25. & Stigmasta-5,23-dien-3.beta.-ol & 64 & 5.97 \\
\hline 26. & Unknown & 15 & 2.85 \\
\hline 27. & Unknown & 18 & 1.53 \\
\hline 28. & Unknown & 15 & 1.17 \\
\hline 29. & Spinasteron & 53 & 4.62 \\
\hline 30 & Sitostenone / delta.4-sitosterol-3-on & 92 & 3.22 \\
\hline 31. & Aurantiamid & 46 & 1.52 \\
\hline
\end{tabular}

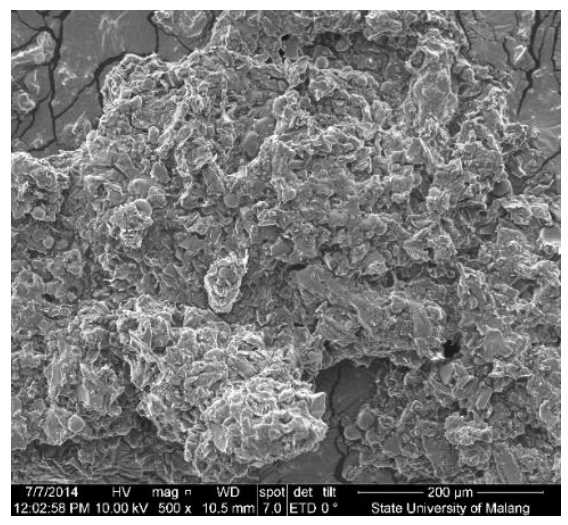

Methanol Extract of Pasak Bumi (a)

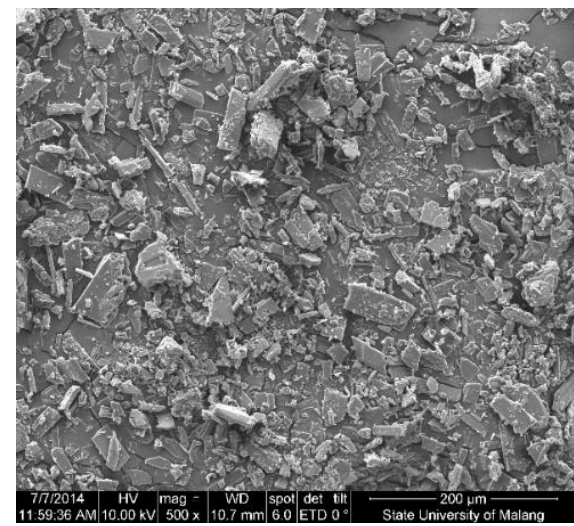

17a-methyltestosterone (Aldrich 69240-5G) (b)

Figure 1 - Characterization and Nanostructures Analysis of methanol extract of Pasak Bumi roots and 17a-methyltestosterone with Scanning Electron Microscope (SEM). Magnification of 500x

The containers used in this research were 15 aquarium units with a size of $60 \times 40 \times 30$ $\mathrm{cm}$. The aquarium was filled with water that has been deposited in a reservoir for one week. Water replacement was carried out with a recirculation system.

Tilapia (Oreochromis niloticus) larvae was obtained from the People's Hatchery Unit (UPR) in Bincau Village, Banjar Regency, South Kalimantan. Retrieval of larvae at 1-day old larvae (egg yolks still exist), for 5-day old, they were kept in the aquarium until egg yolks run out (7-day old), weighing $0.01-0.02 \mathrm{~g} /$ larvae. Larvae that have run out of egg yolks was collected and soaked for 24 hours in Methanol Extract of Pasak Bumi according to the 
dosage of treatment. Subsequently, the larvae was transferred to an aquarium with a density of 50 larvae per aquarium.

Tilapia larvae was fed with shrimp flour with a protein content of $45 \%, 3-4$ times a day with a $5 \%$ feeding rate of biomass for 60 days of culture.

Measuring water quality consisted of water temperature, dissolved oxygen, $\mathrm{pH}$ and $\mathrm{NH}_{3}$. Temperature was measured using a thermometer, dissolved oxygen was measured using DO meter, $\mathrm{pH}$ was measured with $\mathrm{pH}$ meter and $\mathrm{NH}_{3}$ was measured using a spectrophotometer. The parameters of water temperature, dissolved oxygen and $\mathrm{pH}$ were measured every day while $\mathrm{NH}_{3}$ parameters were measured once a week. The temperature during maintenance ranged from $28-30^{\circ} \mathrm{C}$, dissolved oxygen ranged from 5.4 to $6.8 \mathrm{mg} / \mathrm{L}$, $\mathrm{pH}$ ranged from 6.2 to 7.6 and dissolved ammonia ranged from $0.01-0.032 \mathrm{mg} / \mathrm{L}$. Sampling growth and survival rate were carried out every 15 days until the 60 days of trial.

Gonad examination was carried out after the fish was 60 day-old by taking a sample of $30 \%$ of the population of assay fish. The fish was dissected and gonad was taken carefully by using tweezers. A portion of the gonad was placed on the object-glass and then was chopped using a scalpel until the portion became smooth. Then the acetocarmine solution was added. Gonad preparation slides were observed under a binocular microscope with 400X magnification. Some of the gonad samples were made into histological preparations by hematoxylin-eosin (HE) staining. Then their structure was examined using the histological method of exploration.

Measurement of testosterone levels was carried out before and after immersion on 0 , 15, 30, 45 and 60 days. Testosterone levels were measured using the ELISA (Enzym linked immunosobent assay) method, which is an immunoassay method that uses enzymes as a label.

The variance (ANOVA) of the results was analyzed using the STATISTICA 8 at a 95\% confidence level. The data was tabulated with the MS Office Excel 2010. Significantly different treatments were analyzed by using Duncan's technique.

\section{RESULTS AND DISCUSSION}

Masculinization of tilapia by immersion method produced the highest percentage of males in the positive control (MT) of $83.99 \pm 3.33 \%$. Then in EPB3, it was $76.36 \pm 2.79 \%$; in EPB2, it was $75.80 \pm 2.78 \%$; in EPB1, it was $72.66 \pm 2.84 \%$ and in negative control (K-), it was $52.19 \pm 0.00 \%$ (Figure 2). The ANOVA results showed that immersion with methanol extract of Pasak Bumi roots with different doses showed a very significant effect $(p<0.05)$ on the percentage (\%) of male tilapia. Duncan's analysis results showed EPB1, EPB2 and EPB3 were not significantly different but were significantly different from MT $(K+)$ and $K-$.

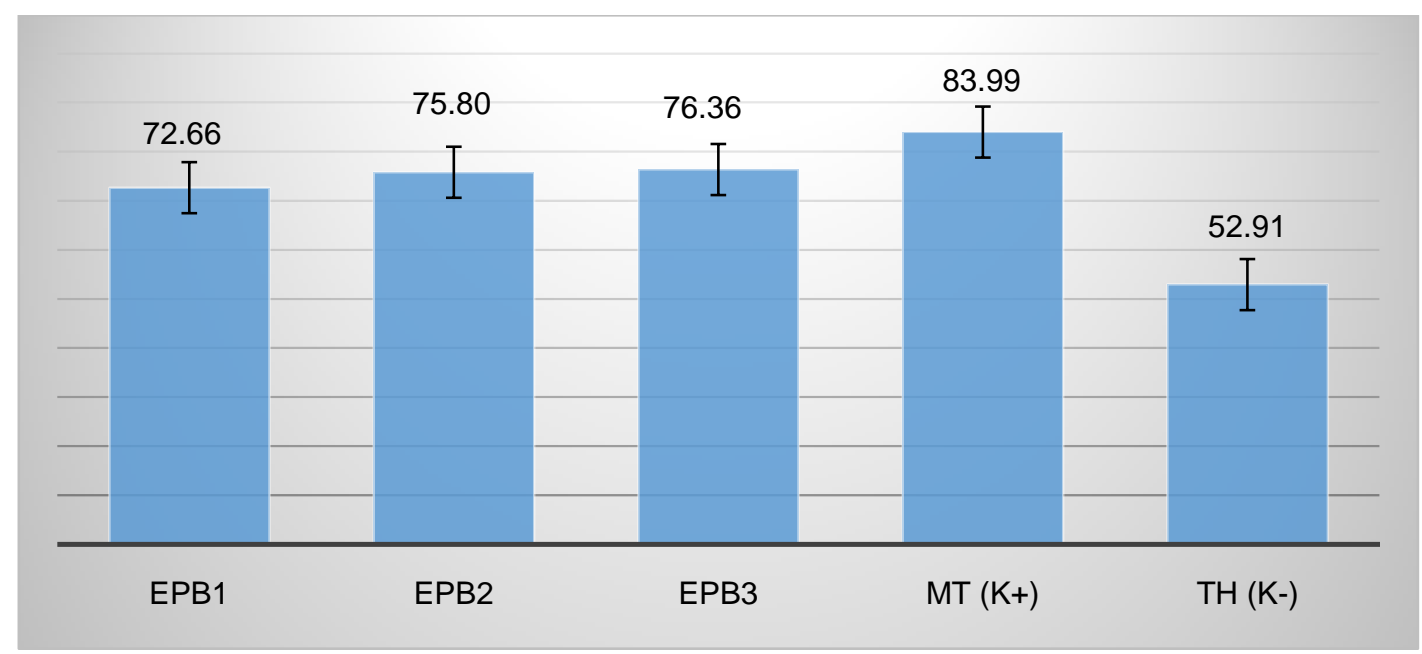

Figure 2 - Percentage (\%) of Male Tilapia by Immersion Method Using methanol extract of Pasak Bumi roots 
Figure 2 showed the sex ratio of male tilapia using methanol extract of Pasak Bumi roots was higher than negative control, but lower than positive control (MT). Based on the medicinal properties contained in the Pasak Bumi plant, aphrodisiac played a role in fish masculinization activities. Aphrodisiacs are medicines, food, drinks, and odors that can cause or increase sexual activity (Taufiqqurrachman, 1999). Pasak bumi roots methanol contained phytosterol compounds, namely stigmasterol from the results of GC-MS analysis (Table 1).

Stigmasterol stimulated an increase in androgen hormones in the body. In addition, a phytochemical screening of Pasak Bumi roots extract contains saponins, phytosterols, alkaloids, and oligosaccharides. The steroid saponin compound is the essential ingredients of the sex hormone industry product. Based on the compounds found in Pasak Bumi roots, stigmasterol, and saponin steroid compounds are thought to improve the quality and male sexual behavior after consuming them (Taufiqqurrachman 1999). The increase in male sex ratio in tilapia is believed to be related to the effect of the stigmasterol compound on the affinity of the androgen receptor so that it can work as an androgen. Tremblay \& Van Der Kraak (1998) suggested that stigmasterol compounds can influence the affinity power of androgen receptors.

The highest intersex tilapia found in EPB1 was at $9.99 \pm 2.84 \%$, and followed by EPB3 at $9.52 \pm 2.79 \%$; positive control (MT) was $7.97 \pm 3.33 \%$; EPB2 was $7.83 \pm 2.78 \%$, whereas negative control did not find intersex fish (Figure 3 ). Analysis of variance (ANOVA) showed that the treatment of methanol extract of Pasak Bumi roots with a different dose had a significant effect $(P<0.05)$ on the intersex of tilapia. Duncan's analysis showed that EPB1 was not significantly different from EPB2, EPB3, and positive control (MT), but very significantly different from negative control (K-).

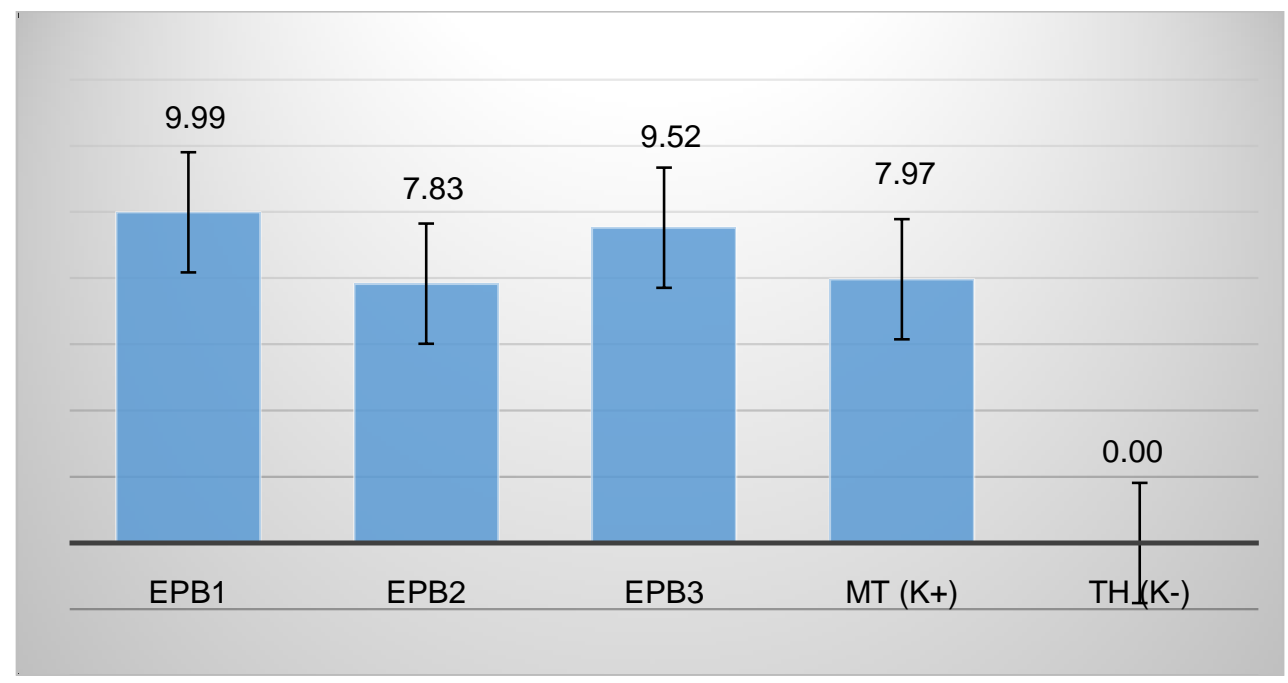

Figure 3 - Intersex Percentage (\%) of Tilapia by Immersion Method Using methanol extract of Pasak Bumi roots

Figure 3 showed 30,60 , and $90 \mathrm{mg} / \mathrm{L}$ treatments and $50 \mathrm{mg} / \mathrm{L}$ positive control (MT) found intersex fish, whereas in the negative control, no intersex fish was found. The intersex value ranged from 7.83 to $9.99 \%$. The highest intersex value occurred at $30 \mathrm{mg} / \mathrm{L}$. It suspected that the content of the stigmasterol compound in the extract of Pasak Bumi given by immersion is still low. This was confirmed by Nakamura et al. (1998) which explained that the administration of steroid hormones with lower doses not able to form males ideally so that it can cause the formation of intersex fish. The intersex phenomenon also occurred in Putra (2011), which showed tilapia with a dose of $20 \mathrm{mg} / \mathrm{L}$ purwaceng extract experienced an intersex of $13.3 \%$ with 8 hours of immersion treatment. Ghosal \& Chakraborty (2014) obtained the percentage of tilapia that experienced an intersex of $7.2 \%$ in the treatment of Tribulus terrestris by immersion method with a dose of $0.05 \mathrm{~g} / \mathrm{L}$ at three day-old. 
The survival rate of Tilapia on the 60 days showed the highest survival rate in EPB2 of $85.33 \pm 3.06 \%$ and subsequently in EPB3 of $84.67 \pm 4.16 \%$; negative control of $83.33 \pm$ $4.62 \%$; positive control (MT) of $82.67 \pm 4.16 \%$, and EPB1 of $80.67 \pm 3.06 \%$ (Figure 4). Analysis of Variance (ANOVA) showed that there was no significant difference $(P>0.05)$ from all treatments on the survival of Tilapia.

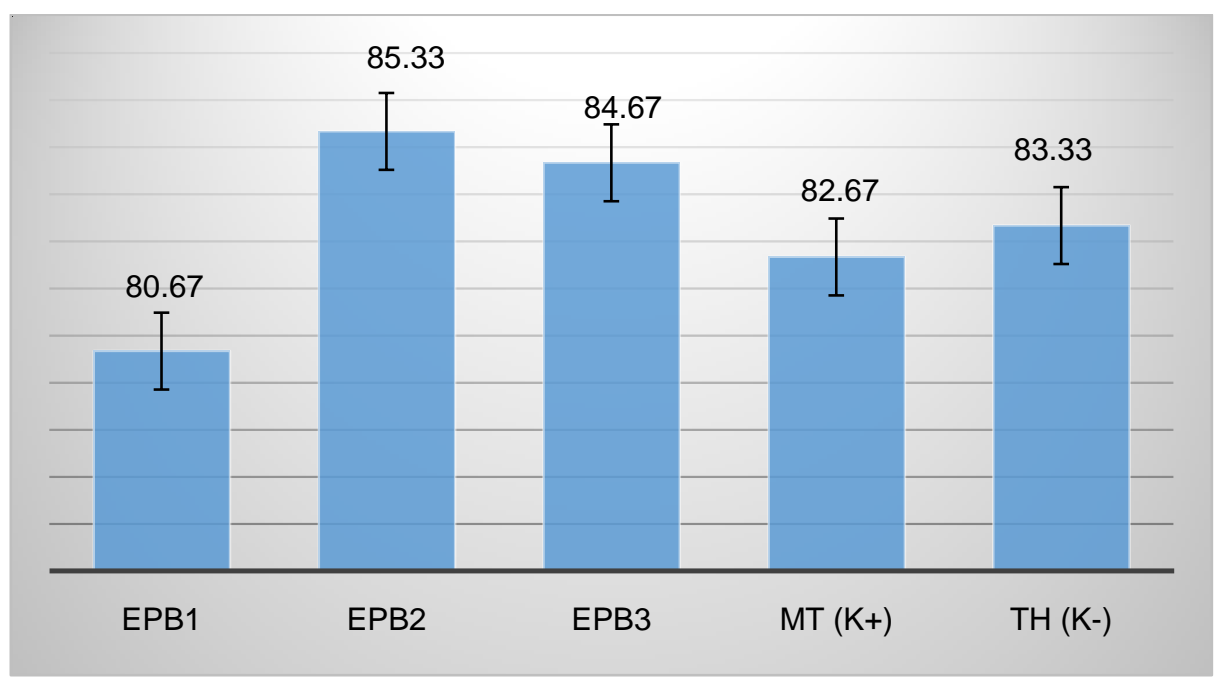

Figure 4 - Percentage (\%) of Survival Rate by Immersion Method Using methanol extract of Pasak Bumi roots

Figure 4 showed the survival rate of tilapia after immersion ranged from $80.67 \%$ $85.33 \%$. The results of this research were similar to those conducted by Ghosal \& Chakraborty (2014) who did masculization with Tribulus terrestris extract, resulting in fish survival from 80.3 to $87.5 \%$. Mukhherjee et al. (2015) reported the use of Asparagus racemsus root extract with immersion method resulted in the highest survival rate of $95.56 \%$.

Daily specific growth (Figure 5) showed the highest growth rate occurred at EPB2 of $0.151 \pm 0.005 \%$ /day, EPB3 of $0.150 \pm 0.005 \%$ /day, positive control (MT) of $0.135 \pm 0.004$ $\% /$ day, EPB1 of $0.134 \pm 0.003 \%$ /day and negative control $0.130 \pm 0.006 \%$ /day. Absolute growth (Figure 6) showed the highest weight gain occurred in EPB2 of $9.08 \pm 0.30$, EPB3 of $9.02 \pm 0.33$, positive control (MT) of $8.13 \pm 0.24$, EPB1 of $8.07 \pm 0.21$ and negative control at $7.80 \pm 0.39 \mathrm{~g}$. Analysis of Variance (ANOVA) showed a significant effect $(P<0.05)$ both on daily specific and absolute growth of Tilapia. Duncan's analysis showed that EPB2 was not different from EPB3, but both were different from EPB1, positive control (MT), and negative control.

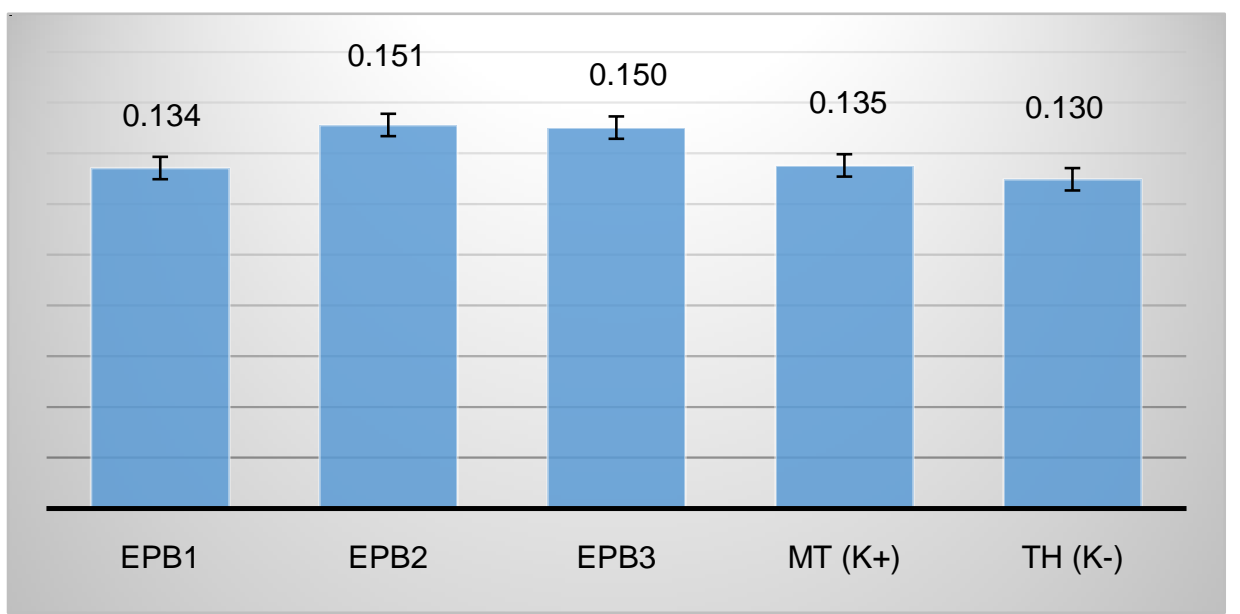

Figure 5 - Daily Growth Rate (\%/day) of Tilapia by Immersion Method Using methanol extract of Pasak Bumi roots 


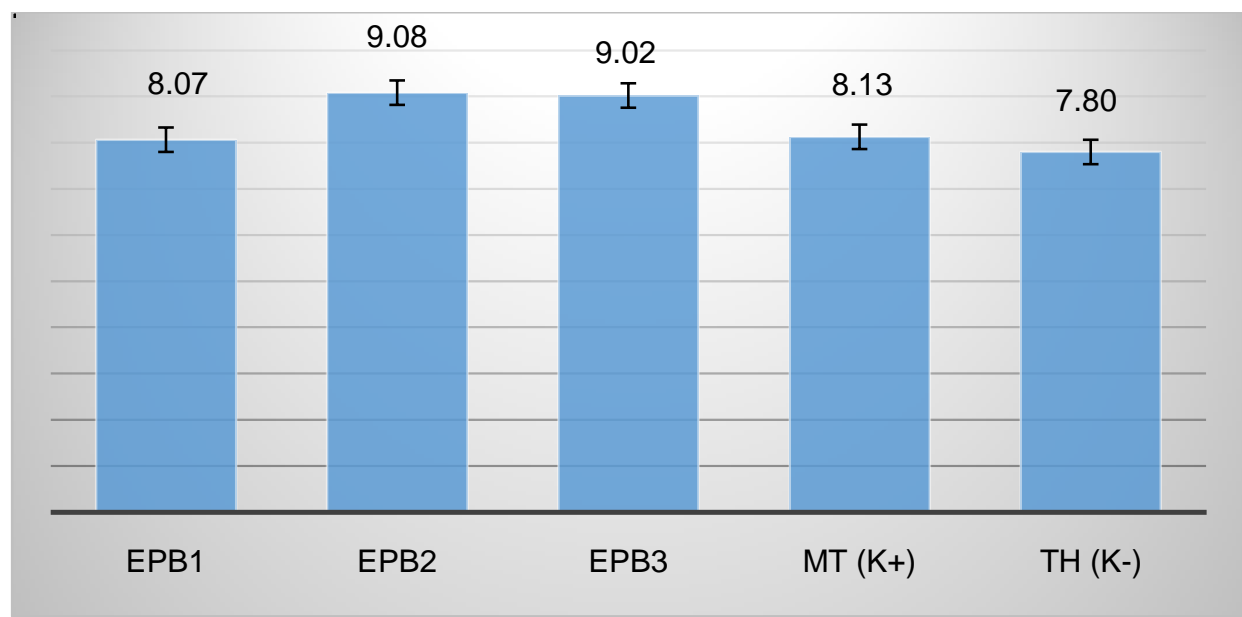

Figure 6 - Weight $(\mathrm{g})$ of Tilapia by Immersion Method Using methanol extract of Pasak Bumi roots

Treatment of $60 \mathrm{mg} / \mathrm{L}$ and $90 \mathrm{mg} / \mathrm{L}$ showed better and higher growth performance compared to other treatments. Phelps \& Popma (2000) stated that androgen hormones have two physiological actions, which are androgenic, which promotes male character, and are anabolic, androgen hormones stimulate protein biosynthesis in fish bodies.

The profile of testosterone in fish larvae was measured by the ELIZA method. Testosterone levels before immersion were at the range of $0.18-0.23 \mathrm{pg} / \mathrm{ml}$. After immersion, testosterone values of EPB1, EPB2, EPB3 and positive control (MT) increased with a range from 0.49 to $0.76 \mathrm{pg} / \mathrm{ml}$, whereas in negative control, there was an increase from $0.218 \mathrm{pg} / \mathrm{ml}$ to $0.225 \mathrm{pg} / \mathrm{ml}$. Furthermore, testosterone levels on 15, 30, 45, and 60 days, EPB1, EPB2, EPB3, and positive control (MT) treatments decreased in tilapia. In the negative control, there was a slight increase in the level of testosterone from15 to 30 days and decreased from 45 to 60 days with a very narrow range of values (Figure 7).

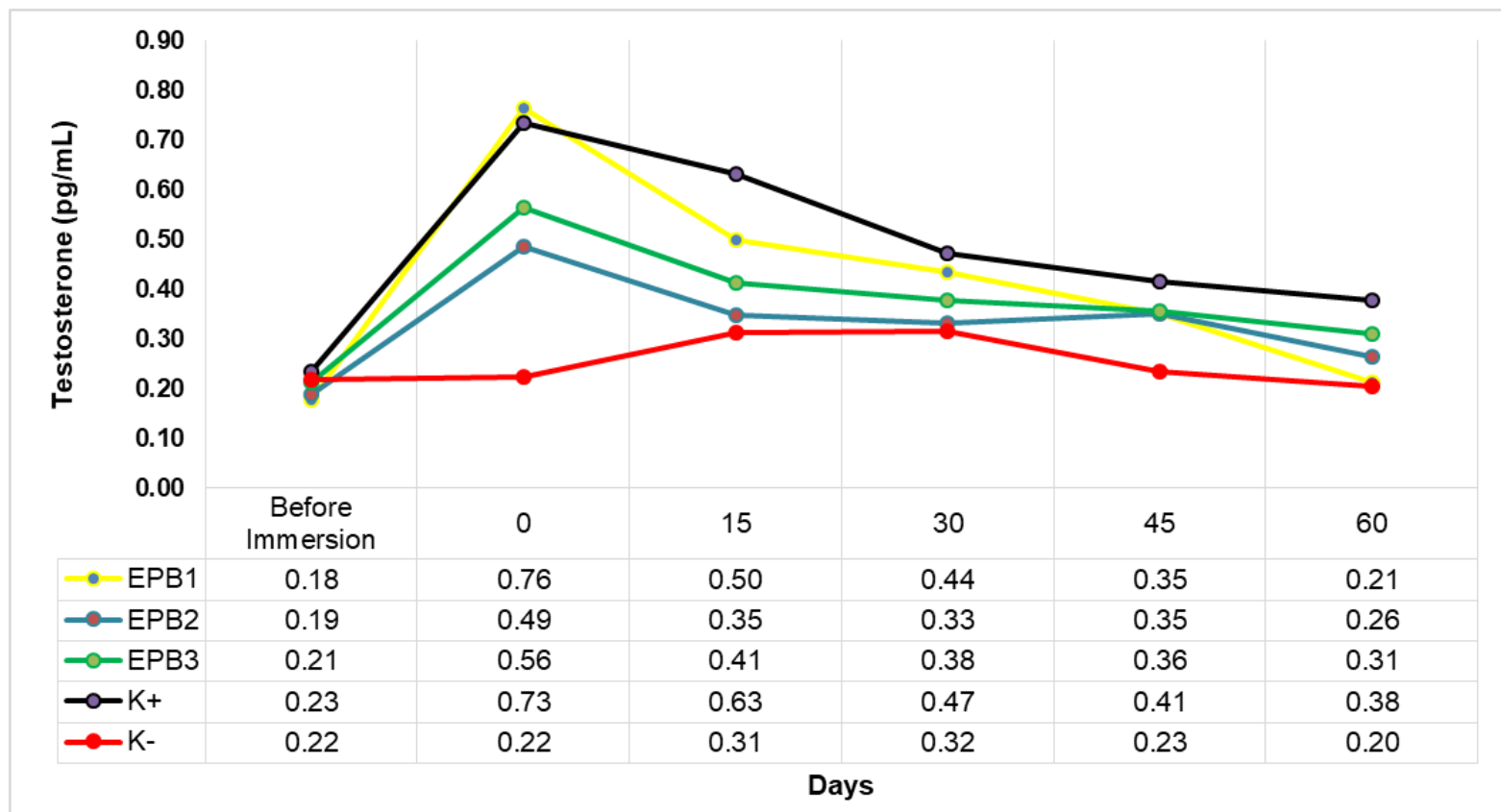

Figure 7 - The concentration of the hormone testosterone in tilapia before and after immersion using methanol extract of Pasak Bumi rootss from 0, 15, 30, 45 to 60 days

The ELISA method was used in this research to measure testosterone concentrations in fish bodies (Memmat et al., 2015). As shown in Figure 7, testosterone levels decreased sharply until the 15 days after immersion, and after that, it tended to be stable until 60 days. 
In negative control treatments, fish testosterone levels were relatively more stable compared to other treatments. A rapid decrease in steroid levels has also been reported by Padian and Kirankumar (2012), who stated that the decrease in steroids occured early at the beginning and gradually stabilized. The level of decrease in hormone levels depended on the species, the purity of the steroid used, the organs detected, and the treatment protocol.

\section{CONCLUSION}

The masculinization of Tilapia (Oreochromis niloticus) using methanol extract of Pasak Bumi roots (Eurycoma longifolia Jack) with immersion method resulted in male sex ratio between $72.66-76.33 \%$, survival rate between $80.67-85.33 \%$, weight gain between 8.07-9.08 g. Thereby, methanol extract of Pasak Bumi roots can be used for masculinization of tilapia by immersion method with the best performance at a dose of 60 and $90 \mathrm{mg} / \mathrm{L}$.

\section{ACKNOWLEDGMENTS}

The authors would like to show a gratitude to the Ministry of Research, Technology and Higher Education of the Republic of Indonesia for the opportunity to obtain a 2011 BPP-DN Scholarship (Domestic Post-Graduate Scholarship).

\section{REFERENCES}

1. Bowman MP, Bowker J, Carty DG, Straus DL, Farmer BD, Mitchell AJ, Ledbetter CK.

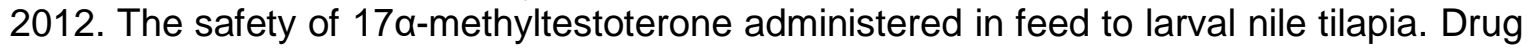
Research Information Bulletin. Aquatic Animal Drug Approval Partnership. 28: 1-3.

2. Bulkini A. 2012. Masculinization of betta fish (Betta splendens) by immersion of embryos in the extract of purwoceng (Pimpinella alpina). [Thesis]. Bogor (ID): Bogor Agricultural University.

3. Cahyani D. 2014. Masculinization of Betta Fish Betta splendens with Extract of Purwoceng Pimpinella alpina with Artemia Immersion [Thesis]. Bogor (ID): Bogor Agricultural University.

4. Carman O, Sastrawibawa S and Alimudin. 1998. Improvement of Genetic Quality by Super Male Production on Mass Red Tilapia (Oreochromis niloticus) in the context of Increasing Production Efficiency (Integrated Research Report IV). Office of the State Minister for Research and Technology. National Research Council. Jakarta.

5. Ghosal I, Chakraborty SB. 2014. Effects of the aqueous seed extract of Tribulus terrestris on sex reversal of nile tilapia. Journal of Pharmaceutical Science. 4: 459-461.

6. Govoroun M, OM McMeel, H Mecherouki, TJ Smith and Y Guiguen. 2001. 17 b Estradiol treatment decreases steroidogenic enzyme messenger ribonucleic acid levels in the Rainbow Trout. Endocrinology, Vol. 142, 5:1841-1848.

7. Memmat, Ml., Reham, A.A., Omaima, MD., Asmaa, EH. 2015. Detection of methyltestosterone and atrenbolone acetate hormones residue in Nile tilapia Oreochromis niloticus. Benha Veterinary Medical Journal 28 (1): 276-280. Pandian TJ, Kirankumar. 2003. Recent advances in hormonal induction of sex reversal in fish. Journal of Applied Aquaculture. 13: $205-230$.

8. Mukherjee D, Ghosal I, Chakraborty SB. 2015. Application Of Asparagus racemosus Roots for Production Of Monosex Nile Tilapia, Oreochromis niloticus International Journal of Advanced Research, Volume 3, Issue 9, 828 - 833.

9. Padian, TJ., Kirankumar, S. 2012. Recent advances in hormonal induction of sexreversal in fish. Journal of Applied Aquaculture 13:205-230.

10. Pandian T.J. 2013. Sex Determination in Fish. New York [US]: Science Publishers. pp $175-224$.

11. Parks LG., Lambright CS., Orlando., EF., Guillette LJ.Jr., Ankleys GT., and Gray LE.Jr. 2001. Masculinization of Female Mosquitofish in Kraft Mill Effluent-Contaminated 
Fenholloway River Water Is Associated with Androgen Receptor Agonist Activity. Toxicological sciences. 62; 257-267.

12. Phelps RP, Popma TJ. 2000. Sex Reversal of Tilapia. in B.A. Costa-Pierce and J.E. Rakocy, eds. Tilapia Aquaculture in the Americas. Volume ke-2. United States [US]: The World Aquaculture Society. pp $39-59$.

13. Piferrer F. 2001. Endocrine Sex Control Strategies for Feminization of Teleost Fish. Aquaculture 197: 229-281.

14. Putra, S. 2011. Masculinization of Nile Tilapia (Oreochromis niloticus) By Immersion Technique in Purwoceng (Pimpinella alpina) Extract. [Thesis]. Bogor (ID): Bogor Agricultural University.

15. Taufiqqurrachman. 1999. Effects of Pimpinella alpina Molk extract. (purwoceng) and Eurycoma longifolia Jack root. (Pasak Bumi) against increased levels of testosterone, LH, and $\mathrm{FSH}$ as well as differences in their increase in male Sprague Dawley rats. [Thesis]. Biomedical Sciences Study Program, Diponegoro University Postgraduate Program. Semarang.

16. Tremblay L. and Van Der Kraak G. 1998. Use of a series of homologous in vitro and in vivo assays to evaluate the endocrine modulating actions of $\beta$-sitosterol in rainbow trout. Aquatic Toxicology 43; 149-162. 